\title{
Polsko-estońsko-angielski elektroniczny słownik tematyczny
}

\author{
Aleksandra Matulewska, Magdalena Wasielewska \\ Institute of Linguistics, Adam Mickiewicz University \\ ul. Międzychodzka 5, 60-371 Poznań \\ matulewski@poczta.onet.pl, m_wasielewska@o2.pl
}

\begin{abstract}
PROJEKT BADAWCZY: Polsko-estońsko-angielski elektroniczny słownik tematyczny Uniwersytet im. A. Mickiewicza w Poznaniu

Kierownik projektu: prof. dr hab. Jerzy Bańczerowski

KBN: 1 H01D 03826
\end{abstract}

Projekt Polsko-estońsko-angielski elektroniczny słownik tematyczny realizowany jest na Uniwersytecie im. Adama Mickiewicza w Poznaniu, na Wydziale Neofilologii w Instytucie Językoznawstwa. Głównymi wykonawcami projektu są mgr Magdalena Wasielewska, mgr Aleksandra Matulewska, Lemmi Erin, dr John Catlow.

Celem projektu jest opracowanie pierwszego tomu dwutomowego słownika polsko-estońskoangielskiego liczącego około 100 tys. haseł (tom 1: 50 tys. haseł, tom 2: 50 tys. haseł).

W chwili obecnej nie istnieje pełne opracowanie leksykograficzne badanego problemu ani na rynku polskim ani angielskim czy estońskim. Brak jest jakiegokolwiek słownika tematycznego polsko-estońskiego na rynku polskim i estońskim. Nie ma również tak obszernego słownika tematycznego angielsko-estońskiego. Główną motywacją do rozpoczęcia badań było to, że zarówno Polska jak i Estonia są krajami, które wstapiły do Unii Europejskiej i kompleksowe opracowanie leksyki polsko-estońskiej obejmującej szeroki zakres tematyczny jest wręcz niezbędne. Przy czym należy dodać, że dotychczas leksykografia polsko-estońska ogranicza się do słownika estońskopolskiego liczącego 10 tys. haseł, który nie zaspokaja istniejących potrzeb na rynku. Ponadto, wydaje się być koniecznym uzupełnienie słownika o chociaż jeden język oficjalnej komunikacji unijnej (w tym przypadku język angielski), który będzie stanowił łącznik komunikacyjny pomiędzy językami państw nowych członków UE a dotychczasowymi państwami członkowskimi UE. Należy dodać, iż słownik tematyczny w formie elektronicznej (CD/DVD) będzie umożliwiał również alfabetyczne wyszukiwanie haseł.

Słownik ten będzie zarówno bazą leksykograficzną dla studentów i thumaczy, jak i biznesmenów, którzy prowadzą rozległe kontakty handlowe w danych państwach. Terminologia tomu 1 obejmuje bardzo istotną tematykę w dobie wstapienia Polski i Estonii do UE oraz członkostwa Polski w NATO ze względu na konieczność thumaczenia dokumentów z języków krajów kandydujących oraz członkowskich. Jest to problem nowy, gdyż język estoński jest językiem do niedawna dyskryminowanym ze względu na brak Estonii jako państwa na mapie Europy. Dopiero w latach 90. jego znaczenie wzrosło i stał się językiem urzędowym w miejsce dotychczasowego języka rosyjskiego (w 1991 proklamowano niepodległość państwa po dwuletnim okresie przejściowym). Wprawdzie istnieją słowniki tematyczne dotyczące wybranych dziedzin, 
niemniej jednak nie wszystkich wymienionych w spisie, a ponadto żaden z tych słowników nie jest kombinacją polsko-estońską.

Metodyka badań będzie polegała na analizie tekstów źródłowych takich jak publikacje fachowe, prasa, czy dokumenty opublikowane w Internecie.

Zwieńczeniem pracy ma być opublikowanie słownika w formie elektronicznej (w roku 2006 tomu 1, a w 2008/9 tomu 2). Ponadto słownik będzie stanowił materiał do publikacji naukowych oraz referatów na temat leksykografii polsko-estońsko-angielskiej wszystkich wykonawców. Baza polsko-angielska będzie jednocześnie wykorzystana do opracowania serii słowników tematycznych Instytutu Językoznawstwa. Obecnie trwają prace nad przygotowaniem wersji węgierskiej, koreańskiej, japońskiej, baskijskiej i hindi (wszystkie te języki są wykładane w Instytucie Językoznawstwa).

W skład pierwszego tomu wchodzić będą następujące działy:

1. Państwo i polityka (Państwo i administracja państwowa; Partie i wybory; Parlament i konstytucja; Polityka zagraniczna, kontakty międzynarodowe).

2. Prawo (Ogólne terminy prawnicze i prawne; Wymiar sprawiedliwości; Prawo cywilne; Prawo karne (przestępczość i ściganie przestępstw); Prawo upadłościowe; Prawo administracyjne; Prawo pracy).

3. Unia Europejska (Nazwy własne; Terminy i wyrażenia; Prawo Unii Europejskiej).

4. NATO (Nazwy własne; Terminy i wyrażenia).

5. Inne organizacje światowe (Nazwy własne; Terminy i wyrażenia).

6. Wojskowość (Nazwy własne; Struktura armii (szczebel taktyczny i operacyjny, stopnie wojskowe); Terminy związane z protokołem dyplomatycznym; Porozumienia rozbrojeniowe i kontrola zbrojeń; Prawo humanitarne; Prawo konfliktów zbrojnych; Uzbrojenie (broń konwencjonalna, chemiczna, biologiczna, jądrowa); Sprzęt wojskowy; Wyposażenie wojskowe; Logistyka wojskowa; Terminologia wojskowa w regulacjach UE; Skróty i akronimy wojskowe). 7. Przemysł i przedsiębiorstwo (Gospodarka, przemysł, branże; Przemysł ciężki; Przemysł lekki; Usługi naprawczo remontowe; Przedsiębiorczość; Biuro i wyposażenie biura).

7. Biznes, handel i finanse (Handel, sklepy; Reklama; Transport, cło; Finanse, bankowość; Papiery wartościowe i giełda; Podatki; Ubezpieczenia; Ekonomia; Biznes i ludzie biznesu; Marketing; Logistyka cywilna).

8. Nauka (Nauka - pojęcia ogólne; Matematyka; Fizyka; Chemia; Językoznawstwo; Historia; Informatyka, multimedia; Pedagogika; Psychologia; Medycyna i skróty medyczne).

9. Nazwy geograficzne (Kontynenty; Państwa; Główne miasta; Nazwy wód i gór; Inne).

10. Liczby, cyfry (Liczebniki; Określenie ilości; Liczebniki zbiorowe; Nazwy cyfr; Liczby, działania matematyczne).

Przedstawione powyżej tematy zostaną ujęte w obrębie rozdziałów w gniazda tematyczne, które poza hasłami głównymi zawierać będą wyrażenia i zwroty. Ponadto opatrzone będą podstawową informacją gramatyczną. Słownik ten zawierać będzie najważniejsze elementy zasobu leksykalnego oraz nowe wyrażenia powstałe $\mathrm{w}$ ostatnich latach odnoszące się do odpowiednich dziedzin rzeczywistości pozajęzykowej. Zostanie on wydany w formie elektronicznej (CD lub DVD w zależności od obowiązującego standardu w momencie wydania). Forma taka ułatwi proces wyszukiwania haseł. Ponadto w dobie społeczeństwa informacyjnego forma elektroniczna oferuje dużo bardziej efektywne możliwości wyszukiwania (szybszy czas dostępu), a użytkownicy częściej sięgają po słowniki elektroniczne niż tradycyjne - w formie drukowanej.

Tom drugi nieobjęty projektem zawierał będzie następujące działy tematyczne:

1. Czlowiek - w rodzinie i społeczeństwie.

2. Ubiór i pielęgnacja ciała.

3. Zdrowie i choroba.

4. Mieszkanie, otoczenie.

5. Komunikacja.

6. Jedzenie.

7. Szkolnictwo i praca.

8. Komunikacja między ludźmi, zwroty potoczne. 


\section{Sport, czas wolny. \\ 10. Kultura i oświata. \\ 11. Przyroda, środowisko, rolnictwo. \\ 12. Czas, kalendarz.}

Poniżej prezentujemy fragmenty $\mathrm{z}$ trzech działów przewidzianych $\mathrm{w}$ słowniku (tu: $\mathrm{w}$ postaci tabel, w słowniku dane te będą zamieszczone w wyszukiwarce programowej ułatwiającej poruszanie się po tak obszernym materiale): 1. Unia Europejska - nazwy własne, 2. Chemia, 3. Sport - gry zespołowe.

Tabela 1. Unia Europejska - nazwy własne

\begin{tabular}{|c|c|c|}
\hline Accession Partnership & Partnerstwo dla członkostwa & Ühinemispartnerlus \\
\hline $\begin{array}{l}\text { ACP Countries (African, Caribean } \\
\text { and Pacific countries) }\end{array}$ & $\begin{array}{c}\text { kraje AKP (Afryki, Karaibów i } \\
\text { Pacyfiku kraje) }\end{array}$ & $\begin{array}{l}\text { Aafrika, Kariibi mere ja } \\
\text { Vaikse ookeani piirkonna } \\
\text { riigid, AKV riigid }\end{array}$ \\
\hline $\begin{array}{c}\text { ACTS }=\text { Advanced } \\
\text { Communications Technologies and } \\
\text { Services }\end{array}$ & $\begin{array}{c}\text { Program Zaawansowanych } \\
\text { Technologii Komunikacyjnych } \\
\text { i Usługowych }\end{array}$ & $\begin{array}{l}\text { programm ACTS [Ühenduse } \\
\text { uuringute, } \\
\text { tehnoloogiaarenduse ja } \\
\text { selgitusprogramm arenenud } \\
\text { sidetehnoloogia ja -teenuste } \\
\text { valdkonnas 1994-1998] }\end{array}$ \\
\hline $\begin{array}{c}\text { Advisory Committee on Safety, } \\
\text { Hygiene and Health Protection at } \\
\text { Work }\end{array}$ & $\begin{array}{c}\text { Komitet Doradczy ds. } \\
\text { Bezpieczeństwa, Higieny i Zdrowia } \\
\text { w Pracy }\end{array}$ & $\begin{array}{c}\text { Nõuandev Tööohutus-, } \\
\text { Tööhügieeni- ja } \\
\text { Töötervishoiukomitee }\end{array}$ \\
\hline Alternative Energy & Altener (Energie Alternatywne) & Alternatiivenergia \\
\hline Amsterdam Treaty & Traktat amsterdamski & Amsterdami leping \\
\hline Andean Pact & Pakt Andyjski & Andide pakt \\
\hline $\begin{array}{c}\text { ASEAN }=\text { Association of South- } \\
\text { East Asian Nations }\end{array}$ & $\begin{array}{l}\text { Stowarzyszenie Narodów Azji } \\
\text { Południowo-Wschodniej }\end{array}$ & $\begin{array}{l}\text { Kagu-Aasia Maade } \\
\text { Assotsiatsioon }\end{array}$ \\
\hline $\begin{array}{c}\text { Association of South-East Asian } \\
\text { Nations }\end{array}$ & $\begin{array}{l}\text { Stowarzyszenie Narodów Azji } \\
\text { Południowo-Wschodniej }\end{array}$ & $\begin{array}{l}\text { Kagu-Aasia Maade } \\
\text { Assotsiatsioon }\end{array}$ \\
\hline $\begin{array}{l}\text { Basic Research in Industrial } \\
\text { Technologies for Europe }\end{array}$ & $\begin{array}{l}\text { podstawowe badania w zakresie } \\
\text { techologii przemysłowych Europy }\end{array}$ & $\begin{array}{c}\text { Euroopa tööstustehnoloogia } \\
\text { alusuuringud }\end{array}$ \\
\hline $\begin{array}{c}\text { BC-Net= Business Cooperation } \\
\text { Network }\end{array}$ & Sieć Współpracy w Biznesie & $\begin{array}{c}\text { Euroopa Ärikoostöövõrk, } \\
\text { BC-Net }\end{array}$ \\
\hline $\begin{array}{c}\text { Behaviour of Materials in the Deep } \\
\text { Sea }\end{array}$ & $\begin{array}{c}\text { Zachowanie Materiałów w Głębinie } \\
\text { Morskiej }\end{array}$ & $\begin{array}{l}\text { Materjalide käitumine } \\
\text { süvameres }\end{array}$ \\
\hline $\begin{array}{c}\text { Benelux Custom / Economic } \\
\text { Union }\end{array}$ & Unia Ekonomiczna Beneluksu & Beneluxi Majandusliit, BLML \\
\hline Benelux Union & Unia krajów Beneluksu & Beneluxi Liit \\
\hline Berne Convention & Konwencja Berneńska & Berni konventsioon \\
\hline bovine spongiform encephalopatia & $\begin{array}{c}\text { bydlęca gabczasta } \\
\text { encefalopatia=choroba szalonych } \\
\text { krów }\end{array}$ & $\begin{array}{l}\text { veiste spongioosne } \\
\text { entsefalopaatia }\end{array}$ \\
\hline $\begin{array}{l}\text { BRIDGE=Biotechnology Research } \\
\text { for Innovation, Development and } \\
\text { Growth in Europe }\end{array}$ & $\begin{array}{l}\text { Badania Biotechnologiczne na rzecz } \\
\text { Innowacyjności, Rozwoju i Wzrostu } \\
\text { w Europie }\end{array}$ & $\begin{array}{l}\text { Euroopa kasvu, arengu ja } \\
\text { innovatsiooni biotehnoloogia } \\
\text { uuringud }\end{array}$ \\
\hline British Steel Corporation & Brytyjska korporacja Stali & Briti Terasekorporatsioon \\
\hline $\begin{array}{c}\mathrm{BSE}=\text { =bovine spongiform } \\
\text { encephalopatia }\end{array}$ & $\begin{array}{c}\text { bydlęca gąbczasta } \\
\text { encefalopatia=choroba szalonych } \\
\text { krów }\end{array}$ & $\begin{array}{l}\text { veiste spongioosne } \\
\text { entsefalopaatia }\end{array}$ \\
\hline Business Cooperation Network & Sieć Współpracy w Biznesie & $\begin{array}{c}\text { Euroopa Ärikoostöövõrk, } \\
\text { BC-Net }\end{array}$ \\
\hline $\mathrm{CAP}=$ Common Agricultural Policy & Wspólna Polityka Rolna & Ühine Põllumajanduspoliitika \\
\hline $\begin{array}{c}\mathrm{CCC}=\text { Consumers Consultative } \\
\text { Council }\end{array}$ & $\begin{array}{l}\text { Rada Konsultacyjna ds. } \\
\text { Konsumentów }\end{array}$ & Tarbijate Nõuandekomitee \\
\hline $\mathrm{CCT}=$ Common Customs Tariff & Wspólna Taryfa Celna & Ühine tollitariif, ÜTT \\
\hline
\end{tabular}




\begin{tabular}{|c|c|c|}
\hline $\begin{array}{l}\mathrm{CDI}=\text { Centre for the Development } \\
\text { of Industry }\end{array}$ & Centrum Rozwoju Przemysłu & $\begin{array}{c}\text { Tööstuse Arendamise Keskus, } \\
\text { TAK }\end{array}$ \\
\hline $\begin{array}{c}\text { Cedefop = European Center for } \\
\text { the Development of Vocational } \\
\text { Training }\end{array}$ & $\begin{array}{c}\text { Europejskie Centrum Rozwoju } \\
\text { Zawodowego }\end{array}$ & $\begin{array}{c}\text { Euroopa Kutseõppe } \\
\text { Arenduskeskus, CEDEFOP }\end{array}$ \\
\hline $\begin{array}{c}\mathrm{CEN}=\text { European Community for } \\
\text { Standardization }\end{array}$ & Europejski Komitet Normalizacyjny & $\begin{array}{l}\text { Euroopa Standardikomitee, } \\
\text { CEN }\end{array}$ \\
\hline $\begin{array}{c}\text { Cenelec }=\text { European Committee } \\
\text { for Electrotechnical } \\
\text { Standardization }\end{array}$ & $\begin{array}{l}\text { Europejski Komitet Normalizacji } \\
\text { Elektrotechnicznej }\end{array}$ & $\begin{array}{c}\text { Euroopa Elektrotehnilise } \\
\text { Standardi Komitee, } \\
\text { CENELEC }\end{array}$ \\
\hline $\begin{array}{l}\text { Centre for the Development of } \\
\text { Industry }\end{array}$ & Centrum Rozwoju Przemysłu & Tööstusarengu Keskus, TAK \\
\hline $\begin{array}{c}\mathrm{CFSP}=\text { Common Foreign and } \\
\text { Security Policy }\end{array}$ & $\begin{array}{c}\text { Wspólna Polityka Zagraniczna } \\
\text { i Bezpieczeństwa }\end{array}$ & $\begin{array}{c}\text { Ühtne välis- ja } \\
\text { julgeolekupoliitika, ÜVJP }\end{array}$ \\
\hline $\begin{array}{l}\text { CMEA = Council for Mutual } \\
\text { Economic Assistance }\end{array}$ & $\begin{array}{c}\text { Rada wzajemnej Pomocy } \\
\text { Gospodarczej }\end{array}$ & $\begin{array}{l}\text { Vastastikuse Majandusabi } \\
\text { Nõukogu, VMN }\end{array}$ \\
\hline Cohesion Fund & Fundusz Spójności & Ühtekuuluvusfond \\
\hline College of Europe & Kolegium Europejskie & Euroopa Kolledž \\
\hline Comitology & komitologia & Komiteede kord, komitoloogia \\
\hline $\begin{array}{l}\text { Commission of the European } \\
\text { Communities }\end{array}$ & Komisja Europejska & Euroopa Ühenduste Komisjon \\
\hline Committee for a People's Europe & Komitet ds. Europy Narodów & Euroopa Rahvaste Komitee \\
\hline $\begin{array}{l}\text { Committee of European } \\
\text { Community Family Organizations }\end{array}$ & Komitet Organizacji Rodzinnych & $\begin{array}{c}\text { Euroopa Ühenduste } \\
\text { Perekonnaorganisatsioonide } \\
\text { Komitee }\end{array}$ \\
\hline Committee of Governors & $\begin{array}{l}\text { Komitet Gubernatorów (banków } \\
\text { centralnych) }\end{array}$ & $\begin{array}{l}\text { Keskpankade Juhatajate } \\
\text { Komitee }\end{array}$ \\
\hline Committee of Ministers & Komitet Ministrów & Ministrite Komitee \\
\hline $\begin{array}{c}\text { Committee of Permanent } \\
\text { Representatives }\end{array}$ & Komitet Stałych Przedstawicieli & $\begin{array}{c}\text { Alaliste esindajate Komitee, } \\
\text { COREPER }\end{array}$ \\
\hline Committee of Regions & Komitet Regionów & Regioonide Komitee, RK \\
\hline Common Agricultural Policy & Wspólna Polityka Rolna & $\begin{array}{c}\text { ühine põllumajanduspoliitika, } \\
\text { CAP }\end{array}$ \\
\hline Common Customs Tariff & Wspólna Taryfa Celna & ühine tollitariif, ÜTT \\
\hline $\begin{array}{c}\text { Common Foreign and Security } \\
\text { Policy }\end{array}$ & $\begin{array}{c}\text { Wspólna Polityka Zagraniczna } \\
\text { i Bezpieczeństwa }\end{array}$ & $\begin{array}{c}\text { ühine välis ja } \\
\text { julgeolekupoliitika, ÜVJP }\end{array}$ \\
\hline Conditions of Roads and Weather & Warunki Drogowe i Pogodowe & Tee ja ilmastikutingimused \\
\hline $\begin{array}{c}\text { Conference on Security and } \\
\text { Cooperation in Europe }\end{array}$ & $\begin{array}{c}\text { Konferencja Bezpieczeństwa } \\
\text { i Współpracy w Europie (KBWE) }\end{array}$ & $\begin{array}{c}\text { Euroopa Julgeoleku ja } \\
\text { Koostöökonverents, CSCE }\end{array}$ \\
\hline Consultative Committee ECSC & $\begin{array}{l}\text { Komitet Doradczy Europejskiej } \\
\text { Wspólnoty Węgla i Stali }\end{array}$ & $\begin{array}{c}\text { Euroopa Söe- ja } \\
\text { Teraseühenduse } \\
\text { Nõuandekomitee, ESTÜ } \\
\text { Nõuandekomitee }\end{array}$ \\
\hline Consumers Consultative Council & $\begin{array}{l}\text { Rada Konsultacyjna ds. } \\
\text { Konsumentów }\end{array}$ & Tarbijate Nõuandekomitee \\
\hline Convention on the Law of the Sea & Konwencja Prawa Morskiego & Mereõiguse Konventsioon \\
\hline $\begin{array}{l}\text { Cooperative Research Action for } \\
\text { Technology }\end{array}$ & $\begin{array}{l}\text { Akcja Wspólnych Badań w } \\
\text { dziedzinie Technologii }\end{array}$ & $\begin{array}{l}\text { Ühiste Tehnoloogiliste } \\
\text { Uuringute Aktsioon }\end{array}$ \\
\hline $\begin{aligned} \text { Coreper } & =\text { Committee of Permanent } \\
& \text { Representatives }\end{aligned}$ & Komitet Stałych Przedstawicieli & $\begin{array}{l}\text { Alaliste Esindajate Komitee, } \\
\text { COREPER }\end{array}$ \\
\hline $\begin{array}{c}\text { Council for Mutual Economic } \\
\text { Assistance }\end{array}$ & $\begin{array}{l}\text { Rada wzajemnej Pomocy } \\
\text { Gospodarczej }\end{array}$ & $\begin{array}{l}\text { Vastastikuse Majandusabi } \\
\text { Nõukogu, VMN }\end{array}$ \\
\hline Council of Europe & Rada Europy & Euroopa Nõukogu \\
\hline Council of European Union & Rada Unii Europejskiej & Euroopa Liidu Nõukogu \\
\hline Council of Ministers & $\begin{array}{c}\text { Rada Unii Europejskiej / Rada } \\
\text { Ministrów }\end{array}$ & Ministrite Nõukogu \\
\hline Court of Auditors & Trybunał Rewidentów Księgowych & Kontrollikoda \\
\hline Court of First Instance & Sąd Pierwszej Instancji & Esimese Astme Kohus \\
\hline $\begin{array}{l}\text { CRAFT=Cooperative Research } \\
\text { Action for Technology }\end{array}$ & $\begin{array}{l}\text { Akcja Wspólnych Badań w } \\
\text { dziedzinie Technologii }\end{array}$ & $\begin{array}{l}\text { Tehnoloogia Ühisuuringute } \\
\text { Aktsioon }\end{array}$ \\
\hline
\end{tabular}


A. Matulewska, M. Wasielewska: Polsko-estońsko-angielski elektroniczny stownik tematyczny

\begin{tabular}{|c|c|c|}
\hline $\begin{array}{c}\text { CROW }=\text { Conditions of Roads and } \\
\text { Weather }\end{array}$ & Warunki Drogowe i Pogodowe & Tee- ja ilmastikuolud \\
\hline $\begin{array}{c}\mathrm{CSCE}=\text { Conference on Security } \\
\text { and Cooperation in Europe }\end{array}$ & $\begin{array}{c}\text { Konferencja Bezpieczeństwa } \\
\text { i Współpracy w Europie (KBWE) }\end{array}$ & $\begin{array}{c}\text { Euroopa Julgeoleku- ja } \\
\text { Koostöökonverents }\end{array}$ \\
\hline $\begin{array}{c}\text { Development of Statistical Experts } \\
\text { System }\end{array}$ & $\begin{array}{l}\text { Program Rozwoju Systemu } \\
\text { Ekspertów Statystycznych }\end{array}$ & $\begin{array}{l}\text { Statistikaekspertide Süsteemi } \\
\text { Arenduprogramm }\end{array}$ \\
\hline $\begin{array}{l}\text { DOSES=Development of } \\
\text { Statistical Experts System }\end{array}$ & $\begin{array}{l}\text { Program Rozwoju Systemu } \\
\text { Ekspertów Statystycznych }\end{array}$ & $\begin{array}{l}\text { Statistikaekspertide Süsteemi } \\
\text { Arenduprogramm }\end{array}$ \\
\hline $\begin{array}{l}\text { EAGGF }=\text { European Agricultural } \\
\text { Guidance and Guarantee Fund }\end{array}$ & $\begin{array}{l}\text { Europejski Fundusz Orientacji I } \\
\text { Gwarancji }\end{array}$ & $\begin{array}{l}\text { Euroopa Põllumajanduse } \\
\text { Arendus- ja Tagatisfond, } \\
\text { EPATF }\end{array}$ \\
\hline $\begin{array}{c}\text { EAST = European Assistance for } \\
\text { Science and Technology }\end{array}$ & $\begin{array}{l}\text { Program Pomocy Europejskiej w } \\
\text { dziedzinie Nauki i Techniki }\end{array}$ & $\begin{array}{c}\text { Euroopa Teaduse ja Tehnika } \\
\text { Abiprogramm }\end{array}$ \\
\hline $\mathrm{EBI}=$ European Investment Bank & Europejski Bank Inwestycyjny & $\begin{array}{c}\text { Euroopa Investeeringupank, } \\
\text { EIP }\end{array}$ \\
\hline $\begin{array}{c}\mathrm{EBRD}=\text { European Bank for } \\
\text { Reconstruction and Development }\end{array}$ & $\begin{array}{c}\text { Europejski Bank Odbudowy I } \\
\text { Rozwoju (EBOR) }\end{array}$ & $\begin{array}{l}\text { Euroopa Rekonstruktsiooni- } \\
\text { ja Arengupank, EBRD }\end{array}$ \\
\hline $\begin{array}{c}\mathrm{EBU}=\text { European Broadcasting } \\
\text { Union }\end{array}$ & Europejskie Zrzeszenie Nadawców & $\begin{array}{c}\text { Euroopa Ringhälinguliit, } \\
\text { EBU }\end{array}$ \\
\hline $\mathrm{ECB}=$ European Central Bank & Europejski Bank Centralny & Euroopa Keskpank \\
\hline $\begin{array}{l}\text { ECCE }=\text { Exchange and Cooperation } \\
\text { between Culture and Enterprise }\end{array}$ & $\begin{array}{l}\text { Program Wymiany i Współpracy } \\
\text { pomiędzy Sferą Kultury i } \\
\text { Przedsiębiorczości }\end{array}$ & $\begin{array}{l}\text { Kultuuri ja Ettevõtluse } \\
\text { Vahetus- ja } \\
\text { Koostööprogramm }\end{array}$ \\
\hline $\begin{array}{c}\mathrm{ECD}=\text { European Community } \\
\text { Defence }\end{array}$ & Europejska Wspólnota Obronna & Euroopa Kaitseühendus \\
\hline $\begin{array}{l}\mathrm{ECHO}=\text { European Community } \\
\text { Office }\end{array}$ & $\begin{array}{l}\text { Biuro ds. Humanitarnych Wspólnot } \\
\text { Europejskich }\end{array}$ & $\begin{array}{l}\text { Euroopa Komisjoni } \\
\text { Teabeorganisatsioon }\end{array}$ \\
\hline $\begin{array}{l}\text { ECIP }=\text { European Community } \\
\text { Investment Partners }\end{array}$ & $\begin{array}{c}\text { Partnerzy Inwestycji Wspólnoty } \\
\text { Europejskiej }\end{array}$ & $\begin{array}{l}\text { Euroopa Ühenduse } \\
\text { Investeeringupartnerid }\end{array}$ \\
\hline $\begin{array}{c}\text { Ecofin }=\text { Economic and Financial } \\
\text { Affairs Council }\end{array}$ & Rada Ekonomiczno-Finansowa & $\begin{array}{c}\text { Majandus- ja } \\
\text { Rahandusnõukogu }\end{array}$ \\
\hline Economic and Monetary Union & Unia Gospodarcza i Walutowa & Majandus- ja Rahaliit, EMU \\
\hline Economic and Social Committee & Komitet Ekonomiczno-Społeczny & Majandus- ja Sotsiaalkomitee \\
\hline $\begin{array}{c}\text { ECSC }=\text { European Coal and Steel } \\
\text { Community }\end{array}$ & Europejska Wspólnota Węgla i Stali & $\begin{array}{c}\text { Euroopa Söe- ja } \\
\text { Teraseühendus, ESTÜ }\end{array}$ \\
\hline $\begin{array}{c}\text { EDF=European Development } \\
\text { Fund }\end{array}$ & Europejski Fundusz Rozwoju & Euroopa arengufond, EAF \\
\hline
\end{tabular}

Tabela 2. Chemia

\begin{tabular}{|c|c|c|}
\hline aberracja, odchylenie & kõrvalekalle, hälve, aberratsioon & aberration \\
\hline abiotyczny, pozbawiony życia & abiootiline & abiotic \\
\hline ablacja, chłodzenie ablacyjne & $\begin{array}{c}\text { kõrvaldamine, (välja)pesemine, } \\
\text { ablatsioon }\end{array}$ & ablation \\
\hline absorbancja; wartość absorpcji & $\begin{array}{c}\text { (spektraalne) neeldumisvõime, } \\
\text { neelduvus, absorbeeruvus } \\
\text { absorbaat, absorbeerunud aine, } \\
\text { neeldunud aine }\end{array}$ & $\begin{array}{c}\text { absorbance; absorbancy; } \\
\text { absorbency }\end{array}$ \\
\hline $\begin{array}{c}\text { absorbat, substancja absorbowana } \\
\text { aine }\end{array}$ & \begin{tabular}{c} 
absorbate \\
\hline $\begin{array}{c}\text { absorbent, substancja absorbująca; } \\
\text { pochłaniacz }\end{array}$
\end{tabular} & $\begin{array}{c}\text { absorbentin } \\
\text { absorbent }\end{array}$ \\
\hline $\begin{array}{c}\text { adenozyn, nukleozyd; składnik } \\
\text { nukleotydów }\end{array}$ & adsorptsioon & adenosine \\
\hline adsorpcja, sorpcja powierzchniowa & aktsentiit, hõbeläik & Adsorption \\
\hline akantyt & aktinoidid & acanthite \\
\hline akceptor & acceptor \\
\hline aktynowce & Actinides =actinide elements \\
\hline
\end{tabular}




\begin{tabular}{|c|c|c|}
\hline aktywność & aktiivsus & $\begin{array}{c}\text { Activity (of a component of ideal } \\
\text { mixture) }\end{array}$ \\
\hline aktywować, uaktywniać & aktiveerima, ergastama & activate \\
\hline aktywowanie, uaktywnianie & aktiveerimine, ergastamine & Activation \\
\hline akumulować; gromadzić & akumuleerima & accumulate \\
\hline $\begin{array}{l}\text { analiza dokumentacyjna, abstrakt; } \\
\text { oddzieleć, usuwać }\end{array}$ & $\begin{array}{c}\text { referaat, kokkuvõte; eemaldama, } \\
\text { eraldama, väljutama }\end{array}$ & abstract \\
\hline ATP, kwas adenozynotrifosforowy & adenosiintrifosfaat & adenosine triphosphate \\
\hline barwniki kwasowe & happelised värvained & acid dyes \\
\hline bezwodnik kwasowy & happeanhüdriid & Acid Anhydride \\
\hline chlorek kwasowy & happekloriidid, kloroanhüdriidid & acid chloride \\
\hline chłodziarka absorpcyjna & absorptsioonspektroskoopia & absorption refrigerator \\
\hline czynny, aktywny & aktiivne & Active \\
\hline dodatek; adj. Addytywny & lisand, manus; lisa-, aditiivne & additive \\
\hline dokładność & täpsus & Accuracy \\
\hline dokładność pomiarów & mõõtmistäpsus, mõõtetäpsus & accuracy of measurement \\
\hline dostępny & kättesaadav; (mõjule) alluv & accesible \\
\hline energia aktywacji & aktiveerimisenergia & Activation Energy \\
\hline guma arabska & kummiaraabik & acacia gum \\
\hline konfiguracja absolutna & $\begin{array}{l}\text { absoluutne konfiguratsioon, } \\
\text { absoluutkonfiguratsioon }\end{array}$ & absolute configuration \\
\hline $\begin{array}{l}\text { kruchość wodorowa; choroba } \\
\text { wodorowa }\end{array}$ & vesinikhaprus & acid brittleness \\
\hline kwas & hape & Acid \\
\hline kwas acetooctowy & atsetoäädikhape, 3-oksobutaanhape, & acetoacetic acid/acetylacetic acid \\
\hline kwas acetylosalicylowy, aspiryna & atsetüülsalitsüülhape & acetylsalicylic acid \\
\hline $\begin{array}{c}\text { kwas adenozyno-5'-dwufosforowy, } \\
\text { ADP }\end{array}$ & adenosiindifosfaat & adenosine-5'-diphosphoric acid \\
\hline kwas nukleinowy & nukleiinhape & nucleic acid \\
\hline kwas octowy & äädikhape, etaanhape & acetic acid \\
\hline kwasy akrylowe & akrüülhape, propeenhape, & acrylic acids \\
\hline nasiąkliwość & $\begin{array}{l}\text { absorbeerimisvõime, neelduvus, } \\
\text { imenduvus }\end{array}$ & absorbability \\
\hline nasiąkliwy & absorbeeruv, neelduv, imenduv & absorbable \\
\hline pasmo absorpcyjne & neeldumisriba & absorption band \\
\hline pochłanianie, absorpcja, wchłanianie & $\begin{array}{l}\text { absorptsioon, neeldumine, } \\
\text { imendumine }\end{array}$ & absorption \\
\hline pomocniczy; dodatkowy & lisaseade, abiseade; tarvik; lisa-, abi- & accesory \\
\hline $\begin{array}{l}\text { przegroda kolumny absorpcyjnej, } \\
\text { paseta }\end{array}$ & absorptsioonikolonni taldrik & absorption tower plate \\
\hline przyspieszacz; akceleator & kiirendi, katalüsaator & accelerator \\
\hline reakcja przyłączenia & liitumisreaktsioon & Addition Reaction \\
\hline rozpowszechnianie & $\begin{array}{l}\text { levimus; rohkus, ohtrus; suhteline } \\
\text { sisaldus }\end{array}$ & abundance \\
\hline sól kwaśna & vesiniksool, van happeline sool & Acid Salt \\
\hline substancja pomocnicza & kõrvalaine & accesory substance \\
\hline $\begin{array}{c}\text { substancja zapobiegająca } \\
\text { przywieraniu }\end{array}$ & abhesioon & abhesion \\
\hline ścierać, zeszlifować & hõõruma; lihvima & abrade \\
\hline ścieranie, szlifowanie & hõõrumine; lihvimine & abrading \\
\hline $\begin{array}{l}\text { ścieranie, zużycie ścierne; miejsce } \\
\text { starte }\end{array}$ & hõõrumine; lihvimine & abrasion \\
\hline
\end{tabular}


A. Matulewska, M. Wasielewska: Polsko-estońsko-angielski elektroniczny stownik tematyczny

\begin{tabular}{|c|c|c|} 
ścierniwo, materiał ścierny; ścierny & abrasiiv(aine), lihvpulber; abrasiiv- & abradant \\
\hline temperatura bezwzględna & $\begin{array}{c}\text { absoluutne temperatuur, } \\
\text { absoluuttemperatuur }\end{array}$ & absolute temperature \\
\hline widmo absorpcyjne & neeldumisspekter & Absorption Spectrum \\
\hline wilgotność bezwzględna & absoluutne niiskus, absoluutniiskus & absolute humidity \\
\hline $\begin{array}{c}\text { współczynnik absorpcji, } \\
\text { absorpcyjność }\end{array}$ & absorbeerimisvõime; neeldumistegur & absorptivity \\
\hline współczynnik pochłaniania & absorptsioonitegur, neeldumistegur & absorption coefficient \\
\hline zero bezwzględne (temperatury) & absoluutne null & Absolute Zero \\
\hline
\end{tabular}

Tabela 3. Sport - gry zespolowe

\begin{tabular}{|c|c|c|}
\hline gry zespołowe & team sports, team games & meeskonnamängud \\
\hline piłka nożna, futbol, piłka & football, soccer & jalgpall, vutt \\
\hline grać w piłkę nożną & to play football & jalgpalli mängima \\
\hline rugby & rugby & rägbi \\
\hline spalony & offside, off-side & suluseis \\
\hline $\begin{array}{l}\text { eliminacje do mistrzostw świata } \\
\text { (Pucharu Świata) }\end{array}$ & World Cup qualifications & $\begin{array}{l}\text { Maailma meistrivõistluste } \\
\text { kvalifikatsioonivõistlus }\end{array}$ \\
\hline reprezentant Polski & Polish international & Poola esindaja \\
\hline kontuzja & injury & vigastus \\
\hline kibice & fans, supporters & fännid, poolehoidjad \\
\hline dogrywka & extra time & lisaaeg \\
\hline pole bramkowe & goal area & väravaala \\
\hline pole karne & penalty area & karistusala \\
\hline linia autowa & touch-line & küljejoon \\
\hline linia środkowa & halfway line & keskjoon \\
\hline linia bramkowa & goal line, by-line & väravajoon, otsajoon \\
\hline środek boiska, pole środkowe & $\begin{array}{l}\text { BE centre/ AE center spot, centre } \\
\text { circle }\end{array}$ & keskring \\
\hline faul & foul, infringement & viga \\
\hline faulować & to foul & viga tegema \\
\hline być / stać na spalonym & to be offside & suluseisus olema \\
\hline piłkarz, futbolista & footballer & jalgpallur, jalgpallimängija \\
\hline kapitan drużyny & captain & meeskonna kapten \\
\hline gracz & player & $\begin{array}{c}\text { jalgpallur, jalgpallimängija, } \\
\text { mängija }\end{array}$ \\
\hline napastnik, atakujący & forward, striker & ründaja \\
\hline pomocnik & $\begin{array}{l}\text { midfield player, midfield, AE inside } \\
\text { (right or left) }\end{array}$ & poolkaitsja \\
\hline (zawodnik) rezerwowy & substitute & varumängija \\
\hline libero, wymiatacz & libero, sweeper & puhastaja, libero \\
\hline trener & coach & treener \\
\hline sędzia główny & referee & peakohtunik \\
\hline sędzia liniowy & linesman & piirikohtunik \\
\hline rozpoczęcie gry & kick-off & avalöök, lahtilöök \\
\hline ustawienie & line-up & rivistus \\
\hline skrzydłowy & winger, wing, AE outside & ääremängija \\
\hline boczny napastnik, skrzydłowy & outside forward (winger) & külgtormaja \\
\hline -lewy / prawy skrzydłowy & $\begin{array}{l}\text { left/right winger/wing, AE outside } \\
\text { right/left }\end{array}$ & vasak/parem ääremängija \\
\hline prawy środkowy & centre-back, $\mathrm{AE}$ right-half & paremkeskmängija \\
\hline lewy środkowy & center-back, AE left-half & vasakkeskmängija \\
\hline obrońca & $\begin{array}{l}\text { defender, fullback, AE right/left } \\
\text { back }\end{array}$ & kaitsja \\
\hline kryjący/środkowy obrońca & $\begin{array}{l}\text { inside/central defender, AE Center } \\
\text { back }\end{array}$ & parem-/vasakkaitsja \\
\hline
\end{tabular}




\begin{tabular}{|c|c|c|}
\hline boczny obrońca & outside defender & külgkaitsja \\
\hline środkowy napastnik & $\begin{array}{l}\text { inside forward (striker), AE center } \\
\text { forward, BE centre forward }\end{array}$ & kesktormaja \\
\hline bramkarz & goalkeeper & väravavaht \\
\hline kopać (piłkę) & to kick (the ball) & palli lööma \\
\hline główkować & to head & peaga lööma \\
\hline -główka & header & pealöök \\
\hline $\begin{array}{l}\text { (za)stosować zwód, kiwać, } \\
\text { dryblować }\end{array}$ & to dribble & triblama \\
\hline drybling & dribble & triblamine \\
\hline drużyna piłkarska & football team & jalgpallimeeskond, meeskond \\
\hline piłka & ball, football & pall \\
\hline poda(wa)ć piłkę & to pass the ball & palli söötma \\
\hline podanie (piłki) & passing the ball & söötmine, sööt \\
\hline podaj! & Pass! & sööda! \\
\hline podać do środka & $\begin{array}{l}\text { to pass (the ball) to the } \\
\text { center/centre }\end{array}$ & keskele söötma \\
\hline dośrodkowanie & $\mathrm{BE}$ to centre, $\mathrm{AE}$ to center & tsenderdamine \\
\hline $\begin{array}{c}\text { podanie/zagranie z pierwszej piłki, } \\
\text { z woleja }\end{array}$ & short pass (one-two) & sööt \\
\hline strzelić gola, zdobyć bramkę & to score & väravat lööma \\
\hline gol & goal kick & värav \\
\hline obronić strzał / gola & to save & lööki tõrjuma \\
\hline remis & draw & viik \\
\hline prowadzić jeden do zera & to lead one to nil & üks null juhtima \\
\hline rzut, strzał & kick & löök \\
\hline rzut karny & penalty, penalty kick & karistuslöök \\
\hline punkt rzutu karnego & penalty spot & penaltimärk \\
\hline czerwona kartka & red card & punane kaart \\
\hline żółta kartka & yellow card & kollane kaart \\
\hline otrzymać żółtą kartkę & to be booked & kollast kaarti saama \\
\hline $\begin{array}{c}\text { dać komuś czerwoną kartkę, } \\
\text { wyrzucić z boiska }\end{array}$ & to send $\mathrm{sb}$ off & $\begin{array}{l}\text { kellelegi punast kaarti andma, } \\
\text { mängust eemaldama }\end{array}$ \\
\hline wykluczenie z gry & sending-off & mängust eemaldamine \\
\hline wrzut piłki z autu & throw-in & palli audist sisse viskama \\
\hline blokowanie & obstruction & blokkimine, blokeerimine \\
\hline jedenastka & penalty spot, eleven-metre mark & $\begin{array}{l}\text { penaltimärk, üheteistkümne } \\
\text { meetri märk }\end{array}$ \\
\hline wskazać jedenastkę & $\begin{array}{c}\text { to order a penalty kick from the } \\
\text { eleven-metre mark }\end{array}$ & penaltit näitama \\
\hline rzut wolny & free kick & vabalöök \\
\hline rzut rożny, róg & corner, corner kick & nurgalöök, nurk \\
\hline wykopywać piłkę & to kick a ball & palli väravast välja lööma \\
\hline buty do piłki nożnej, korki & football boots & jalgpallisaapad \\
\hline - korek & stud & kork \\
\hline - skórzana futrówka & leather lining & nahkvooder \\
\hline - usztywnienie pięty & counter & kannatugevdus \\
\hline - paski wzmacniające & bands & sidemed \\
\hline - skórzany wierzch buta & shaft & jalgpallisaapa nahast pealne \\
\hline - korek wkręcany, wkręt & screw-in stud & vahetatav kork, kork \\
\hline - rowek (na zelówce buta) & groove & saapa pooltallasüvend \\
\hline - podeszwa nylonowa & nylon sole & nailontald \\
\hline - sznurowadło & lace, bootlace & saapapael, pael \\
\hline nagolennik, ochraniacz na goleń & shin-guard, shin-pad & säärekaitse \\
\hline szorty, spodenki & shorts & lühikesed püksid \\
\hline koszulka drużyny & team shirt / jersey & meeskonnasärk \\
\hline getry piłkarskie & sock, football sock & jalgpallisokid \\
\hline środek boiska & centre spot/ center spot & väljaku keskpunkt, keskpunkt \\
\hline mur & wall & sein \\
\hline strzał od bramki & goal kick & väravalöök \\
\hline
\end{tabular}


A. Matulewska, M. Wasielewska: Polsko-estońsko-angielski elektroniczny stownik tematyczny

\begin{tabular}{|c|c|c|}
\hline przyjęcie piłki & receiving the ball, taking a pass & palli/söötu vastu võtma \\
\hline pole gry & field (park) & jalgpalliväljak, väljak \\
\hline piłka do gry w piłkę nożną & football & jalgpall \\
\hline wentyl & valve & ventiil \\
\hline rękawice bramkarza & goalkeeper's gloves & väravavahi kindad \\
\hline wybicie & take-off & hoojooksuga lahtilöök \\
\hline strzelić głową & to head & peaga lööma \\
\hline strzelić & to shoot, to strike & lööma \\
\hline zmieniać zasady w trakcie gry & to move the goalposts & mängu käigus reegleid muutma \\
\hline $\begin{array}{l}\text { boisko piłkarskie // boisko do piłki } \\
\text { nożnej }\end{array}$ & pitch, football pitch & jalgpalliväljak, väljak \\
\hline punkt jedenastu metrów & penalty spot & penaltimärk \\
\hline linia środkowa & half-way line & keskjoon \\
\hline linia boczna & touch line & küljejoon \\
\hline linia szesnastu metrów & sixteen-metre line & kuueteistkümne meetri joon \\
\hline linia pola karnego & penalty area marking & karistusala joon \\
\hline łuk pola karnego & penalty arc & karistusala kaar \\
\hline łuk narożnika & corner arc & nurgakaar \\
\hline koło środkowe & BE centre circle, $\mathrm{AE}$ center circle & keskring \\
\hline pole karne & penalty area & karistusala \\
\hline pole bramkowe & goal area & väravaala \\
\hline bramka & goal & värav \\
\hline słupek & post, goalpost & väravapost \\
\hline poprzeczka & crossbar & põiklatt \\
\hline narożnik & corner & nurk \\
\hline choragiewka (w rogu) & flag & nurgalipp \\
\hline chorągiewka sędziego liniowego & linesman's flag & piirikohtuniku lipp \\
\hline choragiewka pola narożnego & corner flag & nurgalipp \\
\hline choragiewka linii środkowej & centre (AE center) flag & kesksjoonelipp \\
\hline
\end{tabular}

